\title{
Die Calvinisme vandag
}

\author{
A D PONT
}

\section{Inleidende Welkomswoord}

Dit is vir die Kerkhistoriese Genootskap van die Ned Hervormde Kerk ' $\mathrm{n}$ aangename voorreg om $u$ vandag almal by hierdie Kongres welkom te heet. Die Genootskap wat binnekort sy twintigste bestaansjaar sal gedenk, het dit goedgedink om hierdie Kongres aan te bied en om as tema die teologie van die groot hervormer Johannes Calvyn, te kies*. Dit is ' $n$ byna vanselfsprekende tema want die teologie van Calvyn of wel die Bybels-reformatoriese teologie verteenwoordig één van die gemeenskaplike fasette van die drie Afrikaanse kerke. Daarby is die Calvinistiese teologie seker één van die sterkste steunpilare van die Afrikaner se Christelik-nasionale lewens- en wêreldbeskouing. Sou mens vandag soek na gemeenskaplike momente in ons geestes-erfenis dan is die geestelike nalatenskap van Johannes Calvyn seker van eminente belang. Die Genootskap het geoordeel dat 'n kongres rondom die teologie van Johannes Calvyn óók kan bydra tot'n positiewe gedagtewisseling tussen diegene wat in meerdere of mindere mate hulle besighou met die bestudering van die lewe en werk van die groot hervormer. Selfs dít is in ons gejaagde moderne samelewing nie altyd moontlik nie. Daarom is ons besonder dankbaar dat die verskillende historici én navorsers hulle bereid verklaar het om hier 'n referaat te kom hou.

Dit is vir die Genootskap dan ook 'n besondere genoeë om die bekende Duitse Calvyn-kenner, prof dr Hans Helmut Esser, hier in ons midde te verwelkom. Afkomstig van die Wesfaalse Universiteit Münster waar hy hoof is van die Reformiertes Seminar van die Teologiese Fakulteit aldaar, het hy die tyd en die geleentheid gevind om óók ons Kongres te kom toespreek. Afgesien van sy verskillende publikasies was hy ook een van die hoofsprekers in 1974 op die Europese Kongres oor Calvynnavorsing wat in Amsterdam gehou is. Ook vanweë hierdie feit is ons dankbaar dat hy in ons midde is om so ons op hoogte te hou van die navorsing wat in Europa gedoen word.

Net so is dit ook vir die Genootskap 'n saak van vreugde dat die volywerige prof dr B Spoelstra ons sal toespreek. As kerkhistorikus van die Gereformeerde Kerke met sy direkte werkkring by die Teolo-

*Die eerste ses artikels in hierdie uitgawe is voordragte wat tydens 'n Kongres oor Calvyn van die Kerkhistoriese Genootskap van die Ned Hervormde Kerk op 10 en 11 Augustus 1977 in Pretoria gehou is. 
giese Opleidingsentrum te Hammanskraal, het ons al meerdere mate voordeel getrek van prof Spoelstra se navorsingswerk en insig.

Jammer genoeg moes prof dr T N Hanekom, die onlangs afgetrede kerkhistorikus van die Universiteit van Stellenbosch, ons laas week laat weet dat weens omstandighede hy nie in staat sal wees om teenwoordig te wees nie. Dit spyt ons terdeë want sy tema, Die Calvinisme in Suid-Afrika, histories besien, sou inderdaad 'n besondere bydrae kon gewees het. Prof Hanekom wat'n leeftyd lank hom aan die Kerkgeskiedenis gewy het, was en is eminent geskik om oor hierdie tema te handel. Ons hoop dat dit nog moontlik sal wees om sy bydrae vir' $n$ eventuele publikasie te verkry. Dan wil ons ook ons dank uitspreek dat prof dr B J Engelbrecht die dogmatikus van die Universiteit van Pretoria se Hervormde Teologiese Fakulteit asook prof dr $\mathrm{F}$ $\mathrm{J}$ van $\mathrm{Zyl}$, hoogleraar in Godsdiens- en Sendingwetenskap, hier sal optree. Hulle deelname kan gesien word as deel van die bydrae wat ons Genootskap tot hierdie Kongres maak. Deur die voordragte én die bespreking wil die Genootskap met hierdie Kongres andermaal die aandag vestig op die Bybels-reformatoriese teologie van Johannes Calvyn. Hoewel dit so is dat "die Calvinisme" vandag die sondebok gemaak word vir baie van die wêreld se eie-tydse probleme, hoewel die vroeëre Anglikaanse aartsbiskop van Kaapstad in die jare sestig 'n mode geskep het toe hy die sg. "primitive calvinism" van die Afrikaner as díe grondoorsaak van ál Suider-Afrika se probleme, aangedui het, het dít die belangrikheid van Calvyn se interpretasie en verstaan van Gods Woord en God se wil nog nié werklik geskaad nie. Want één primêre uitgangspunt wat Calvyn ten opsigte van sy werk gestel het, maak van hom as't ware 'n tydlose teoloog en dit is sy ideaal om ' $n$ eerbiedige Skrifteoloog te wees. Al Calvyn se arbeid word immers beheers deur die feit dat hy slegs wou luister na God se geopenbaarde waarheid, dat hy in onvoorwaardelike eerbied die Skrif alléén wou laat spreek en slegs wou sê wat die Bybel sélf sê. Daarom is en bly Johannes Calvyn tot vandag toe vir elke Bybels-reformatoriese teoloog ' $n$ belangrike getuie van die Waarheid na wie ons graag luister. Daarby kom dat die Belydenisskrifte van die drie Afrikaanse kerke, die Formuliere van Enigheid, aldrie baie duidelik produkte van die Calvinistiese teologie is. So is die riglyn én norm van ons kerklike prediking, ons evangelie verkondiging, duidelik Calvinisties, terwyl ook ons kerkinrigting en ons kerklike gebruik baie duidelik die stempel van die teologie en insig van Johannes Calvyn dra.

Dit is dus glad nie so vreemd dat ons vandag in hierdie tye van woelinge en verandering weer ' $n$ oomblik sal stilstaan om na te dink en na te vors wat Calvyn vir ons te sê het nie. Want as ons vra na die teologie van Calvyn, dan vra ons eintlik na Gods Woord self. Calvyn immers wou nooit iets ánders doen nie as om sélf terug te keer na die 
suiwere eenvoud van die oorspronklike Christendom, na die duidelike Woord van God, na die ondubbelsinnige evangelie van Jesus Christus nie.

Hoewel ons, wat die verlede betref, met groot stelligheid kan sê dat die teologie van Calvyn ' $n$ waardevolle funksie in ons vaderland vervul het, kom die vraag na vore of dit óók die toekoms geld? Is daar inderdaad aanleiding om te dink dat die Calvinisme of die Bybels-reformatoriese teologie nog ' $n$ belangrike taak het in die tyd wat vóór ons lê?

Om 'n antwoord, al is dan ook ' $n$ voorlopige antwoord, op dié vraag te vind, het die Kerkhistoriese Genootskap hierdie Kongres belê en' $n$ paar temas gesoek wat in hierdie verband van belang kan wees.

\section{Die Calvinisme Vandag.}

As hierdie tema bekyk word, dan is dit seker moontlik om dit so te verstaan dat 'n oorsig gegee moet word van die verspreidheid van die Calvinisme as Bybels-reformatoriese teologie en as ' $n$ bepaalde teologie wat deur sekere kerke as bepalend aanvaar is. Dan sal dit nodig wees om na te gaan of die Calvinisme nog dominant is in Genéve en wat die invloed en reikwydte van die Calvinisme is in die Engelssprekende wêreld, in Frankryk, Nederland, Duitsland en ook hier by ons.

So ' $n$ beskrywing, so wil dit voorkom, kan 'n moeilike indien nie onmoontlike onderneming word. Baie kerke in Europa en die Engelssprekende wêreld wat formeel nog Calvinistiese belydenisskrifte handhaaf, is wat hulle beoefening van die teologie en hulle evangelieverkondiging betref volledig in teenspraak met hulle Calvinistiese herkoms en die Calvinistiese belydenisskrifte. Hoewel dit so is dat in daardie kerke en gemeenskappe wat van Calvinistiese oorsprong is, daar tog nog baie van Calvinistiese erfgoed oorgebly het, is dit óók so dat die mode-teologie van ons tyd, die social gospel en sy derivate, vir 'n baie groot deel die Bybels-reformatoriese teologie oorspoel het. Onder druk van die sosialisme en die denkwêreld wat sy oorspronge in die Aufklärung en die daaraan voorafgaande sestiende-eeuse Renaissance-Humanisme het, is dit vandag die mode om vanuit die mens en die kennis van die mens oor God te praat. Dit het in Nederland meegebring dat ' $n$ inrigting soos die Vrije Universiteit van Amsterdam feitlik elke beginsel wat met die stigting van daardie inrigting voorop gestel is, in die praktyk verwerp het. Die kerk van John Knox, die Presbiteriaanse Kerk, veral in Amerika in die gestalte van die United Presbyterian Church en ook elders in die Engelssprekende wêreld, het veel eerder die draer geword van die humanistiese social gospel as van die Woord van God wat deur die reformatoriese vadere so sterk op die voorgrond geplaas is. Dit is en 
bly ' $n$ merkwaardige saak dat juis reformatoriese kerke wat hulleself Calvinisties noem, wat belydenisskrifte behou wat 'n samevatting van die Calvinistiese teologie is, so maklik daardie erfenis verloën en verloën het. Dit word egter verstaanbaar as mens die Dordtse Leerreëls van 1619 nalees en ook besef dat genade nie erfgoed is nie. Selfs hier in ons eie vaderland sal 'n ondersoek na die verspreidheid en die seggenskap van die Calvinisme nie 'n eenvoudige aangeleentheid wees nie. Hoewel ons Afrikaanse kerklike gemeenskap in leer en lewe wél die stempel van die Calvinisme dra, is dit ook duidelik dat die teologie van Johannes Calvyn of die leer van die kerklike belydenisskrifte vir baie Afrikaanse teoloë alleen historiese interessantheidswaarde het. Ook hier het die social gospel en sy uitlopers ook al sy aanhang verwerf.

Dit wil natuurlik nié sê dat die teologie van Johannes Calvyn 'n vergete saak geword het nie. Indien kennis geneem word van $D$ Kempff, A Bibliography of Calviniana 1959-1974 dan blyk dit wel dat daar 'n steeds voortgaande navorsing-, studie- en publikasieprogram ten opsigte van die Bybels-reformatoriese teologie dwarsoor die beskaafde wêreld bestaan. Dit is wel waar dat hierdie studiewerk nie internasionaal gekoördineer is nie net soos dit waar is dat die navorsing, studie en publikasies rondom Calvyn en die Bybels-reformatoriese teologie in Suid-Afrika ook nie gekoördineer is nie. Die indruk bestaan dat selfs op die wetenskaplik-teologiese terrein daar sulke hoë mure tussen die drie Afrikaanse kerke bestaan dat daar oor en weer skaars van mekaar se publikasies of navorsingsresultate kennis geneem word. Dit laat die indruk ontstaan dat die Calvinisme'n verdelende faktor in ons kerklike lewe is terwyl Calvyn se hele teologie en arbeid juis van die teendeel getuig.

Daarom is dit nie onbelangrik dat prof dr $\mathrm{H} \mathrm{H}$ Esser, een van die toonaangewende Calvyn-kenners van Wes-Europa hierdie Kongres bywoon nie. Op dié manier ontstaan daar tóg 'n skakeling en dan wel op 'n vlak wat op die lang duur meer vrugte behoort af te werp as die "ekumeniese" bedrywighede wat op 'n ander lees geskoei is as die Bybels-reformatoriese teologie.

\section{3 'n Tematiese Benadering}

As ons aanneem dat by 'n bespreking van Die Calvinisme Vandag 'n statistiese oorsig van die Calvinisme en moeilike onderneming is, sal 'n tematiese oorsig waarskynlik die enigste wees wat oorbly. Dan kom die vraag na vore wat ons onder Calvinisme wil verstaan want dit is duidelik dat vir voor- en teenstander dié woord nie altyd dieselfde beteken nie. Vir die doeleindes van hierdie oorsig word met Calvinisme bedoel die Bybels-reformatoriese teologie van Johannes 
Calvyn self. Dit is inderdaad noodsaaklik om so af te grens want reeds by Calvyn se onmiddellike opvolgers kom daar aksentverskuiwings wat nie in Calvyn se eie teologie bestaan het nie.

As dan in hierdie sin oor Die Calvinisme Vandag gepraat moet word, is daar tog 'n opmerking van Calvyn wat as't ware vanself na vore kom. In sy geskrif van 1543, gerig aan keiser Karel V, getittel De necessitate reformandae ecclesiae, sê Calvyn onder andere:

"Hulle beskou die toestand van die kerk as so bedorwe dat hulle reeds vooraf verklaar dat die gebruik van enige hulpmiddel tevergeefs sal wees aangesien daar tog geen moontlikheid van genesing bestaan nie ... Hulle wat só dink, weet nie dat kerkvernuwing eintlik ' $n$ werk van God is wat net so min van menslike verwagtings en hoop afhanklik is as die opstanding uit die dode of ' $n$ derglike soort wonder. Die moontlikheid om hierin handelend op te tree word nie of deur die natuurlike welwillendheid van die mens óf deur gunstige tydsomstandighede gegee nie maar hier geld die reël om ondanks álle twyfel voort te gaan. Die Here God wil dat sy evangelie verkondig sal word. Ons wil aan hierdie opdrag gehoorsaam wees en gaan waarheen Hy ons roep. Om na resultate te vra, is nie ons taak nie..."

Hoewel die saak van kerkhervorming of kerkherstel hier nié primêr aan die orde is, soos in die uitspraak van Calvyn nie, is dit tog so dat die algemene toestand van kerk en wêreld vandag 'n mens nie tot rasende optimisme dwing nie. Veral hier in Suider-Afrika is die algemene toestand van so' $n$ aard dat vele hulle daaroor sorge maak. Nie alleen het die internasionale kommunisme daarin geslaag om die Christelike beskawing in Suider-Afrika op die verdediging te dwing nie, maar dit is ook so dat van vele kante kapitulasie aan die volksvreemde vandag verkondig word as die hoogste roeping van kerk en volk in Suid-Afrika self. Vele ideologieë en filosofieë word vandag met netjiese verkoopkuns aan die mense van Suider-Afrika voorgehou én aanbeveel as ' $n$ oplossing van al die probleme van hierdie deel van die vasteland. Geen wonder dat daar by vele in ons vaderland ' $n$ gevoel van onsekerheid, koersloosheid, toekoms- bevreesdheid en selfs twyfelende onrus posgevat het nie.

In hierdie situasie staan óók die Calvinisme vandag en die vraag kom dan óf -daar vir die Calvinisme, die Bybels-reformatoriese teologie ' $n$ taak en 'n toekoms is. Of moet ons ewe gelate maar aanvaar dat net soos die Islam die Christendom van Noord-Afrika oorspoel het, die barbarisme van Afrika, aangevuur en bewapen deur die lande van die sosialistiese wêreld, die Christelike geloof en beskawing hier sal oorspoel soos in die res van Afrika? 


\section{Die opdrag tot evangelieverkondiging}

Die antwoord op die bestaande situasie, wat die Calvinisme betref, word tóg deur Calvyn sélf gegee as hy sê: "Die Here God wil dat sý evangelie verkondig sal word. Ons wil aan hierdie opdrag gehoorsaam wees en gaan waarheen Hy roep".

Hier moet ons dadelik onderstreep dat dit om die regte evangelieverkondiging gaan, die verkondiging van Jesus, die Christus volgens die Skrifte. Evangelieverkondiging beteken by Calvyn niks anders as die uitdra van die vrolike boodskap van die redding van die sondaar deur Jesus Christus die Verlosser nie. Evangelieverkondiging, verkondiging van God se goeie boodskap aan die mensdom, word nooit deur die tydsomstandighede bepaal nie. Die teendeel is eerder waar want in sy Institutio IV. 7.24 stel Calvyn:

"Daar is geen ander rede waarom die pous met sulke woede teen die nuwe prediking van die evangelie te kere gaan nie en ook al sy krag inspan om dit te onderdruk nie en ook alle konings en vorste tot wrede onderdrukking aanspoor nie as dat hulle bemerk dat hulle hele heerskappy inmekaarval en ineenstort sodra die evangelie werklik tot geldigheid kom".

Evangelieverkondiging, regte evangelieverkondiging breek sy eie baan en vir Calvyn is dit duidelik dat sonder die Verlosser Jesus Christus daar nie sprake van 'n verlossing kan wees nie en dat die mens alléén deur die geloof in Jesus Christus die heil kan ontvang.

In ons tyd waar dit mode geword het om vanuit die ideologieë van die wêreld die Skrif om te buig om sodoende daardie opvattings Skriftuurlik te "regverdig", het dit miskien nodig geword om weer 'n keer te luister na 'n opmerking van Karl Barth. In 1936 het hy met die geleentheid van 'n herdenking van Calvyn te Genéve gesê:

"Elkeen wat 'n leerling van Calvyn word, word 'n leerling van die Heilige Skrif. Ons is hom dankbaar dat hy die Heilige Skrif nie net geroem het nie, maar dat hy ook vir ons ' $n$ voorbeeld van 'n teologiese lewenstyl voorgeleef het ... naamlik dié van 'n leser én 'n uitlegger van die Heilige Skrif, wat in die Skrif nie sy eie gedagtes teruggevind het nie maar daar God se gedagtes gesoek en gevind het".

Kerk én wêreld in Suider-Afrika, gepla en omgewoel deur die ideologieë van die Ooste en die Weste, beroer deur die fanatisme van 'n derde wêreld wat sy eie onvermoëns probeer verberg agter ' $n$ stortvloed van eise, het God se gedagtes, God se Woord nodig in ál sy reformatories-calvinistiese eenvoud, skerpte en troos.

As die Calvinisme, as ons wat onsself in meerdere of mindere mate volgelinge van Johannes Calvyn noem in ons eíe tyd ' $n$ roeping én ' $n$ 
opdrag het dan is dit om die evangelie te verkondig, die onvervalste Woord van God. Dan wéét ons verder dat oral waar die Woord verkondig, gehoor en geglo word, dáár skep God die Heilige Gees 'n gemeente. Mens kan selfs sê dat die stelling omgekeer kan word naamlik dat 'n gemeenskap, 'n gemeente geskep word om die verkondiging van die evangelie te hoor, te verstaan én te glo. In dáárdie gemeenskap word die Waarheid van die Woord verwerklik.

\section{Evangelie en Praktyk}

Juis met hierdie standpunt het Johannes Calvyn óók vir ons van vandag nog iets te sê. Sy stelling dat die geloof in Christus ons óók roep tot dade van dankbaarheid, sy stelling dat ons dankbaarheid vir die verlossing deur Jesus Christus nie nét tot 'n dankbare gesind heid beperk kan bly nie, het juis aan sy teologie, aan die kerke wat die stempel van sy teologie dra, 'n besondere daadkrag gegee.

Die kerk, die gemeente wat in aansyn geroep word deur die evangelieverkondiging om daardie verkondiging te hoor, te verstaan en te glo word opgeroep om God met siel en gees en liggaam te dien én te eer.

"Die diens van God", so stel Calvyn dit in sy Johannes-kommentaar 4:23, "bestaan in die Gees want dit is niks anders as daardie innerlike geloof van die hart wat die gebed na vore roep en verder suiwerheid van gewete en selfverloëning sodat ons toegewy mag wees aan die gehoorsaamheid van God soos heilige offerandes".

Die diens van God omvat die volle gehoorsaamheid aan die eerste én die tweede tafel van die Wet maar dan altyd só gesien dat die gelowige se horisontale dankbaarheidsdiens vóórtvloei uit die primêre vertikale verhouding wat God self, eiemagtig tot stand gebring het. Hierdie diens van God het dan ook 'n omvangryke breedte want in 'n preek oor Psalm 148 stel Calvyn -

"As 'n mens die eer van God verswyg, beteken dit om die natuurlike orde om te keer, om die lig van die son te blus".

Waar die geloof kwyn of verdwyn, gaan die skepping ten gronde, waar die ware diens van God gestaak word, tref die oordeel van God land en volk. Evangelieverkondiging én gehoorsaamheid aan die evangelie is in ons bedeling, so gesien, baie belangriker as verbygaande populariteit deur die evangelie "aan te pas" aan die eise van die tyd.

Hoewel Brillenburg-Wurth in 'n pragtige opstel oor Calviin en het Koninkrijk Gods reeds in 1959 al gesê het dat Calvijn se teokratiese opvattings nie meer so goed bruikbaar is in ons moderne wêreld nie, 
wil dit tog voorkom asof dit steeds méér nodig word om met klem die eer van God in ons moderne wêreld te verkondig. Die verhorisontalisering in die hedendaagse teologie waar die één genitief-teologie na die ander opstaan, die geneigdheid om kerk én teologie in 'n diensbaarheid te dwing aan die opvattings van die meerderheid maak dit al méér en méér noodsaaklik om die eer van God na vore te bring, die soewereiniteit van God te bly beklemtoon.

Van daar uit kan kerk en teologie die hele problematiek van die praktiese lewe van die samelewing vanuit Gods Woord onder die troos én oordeel van die evangelie stel. Tereg stel Calvyn dat God ingryp in die wêreld en in die lewe van die mens en nié andersom nie. Die vertikale gaan aan die horisontale vóóraf en die horisontale word eers vanuit die vertikale verstaanbaar. Dink maar weer aan die beroemde openingsin van die Institutio:

"Nagenoeg die hele hoofsom van ons wysheid, wat eers ware en soliede wysheid geag moet word, bestaan uit twee dele: die kennis van God én van onsself".

Dáárdie kennis, waarvan Calvyn praat, is nie ' $n$ intellektuele insig of 'n redelike kennis-sekerheid nie, maar 'n omskrywing van die lewende, persoonlike betrekking tussen God en mens. Dan beklemtoon Calvyn dat ware selfkennis alleen gebore word uit die konfrontasie met God soos ons Hom in sy Woord ontmoet. Hier lê Calvyn se geniale koppeling van teologie en praktyk wat juis aan sy denke 'n voortdurende jeug gee. Immers vir Calvyn is hierdie tweevoudige kennis, die kennis van God as Heer én as Vader. Die selfkennis van die mens is die kennis dat die mens 'n gevalle skepsel, ' $n$ sondaar is maar ook in en deur Christus 'n verloste kind van God is wat nou in alles tot sy oorspronklike bestemming teruggelei word en geroep word om in alle lewensverbande God te dien én te eer.

Wat dit alles in besonderhede beteken in die lig van die Woord kan nie hier uitgespel word nie. Die feit bly egter dat hierdie prinsipiële, Skriftuurlike visie van Calvyn grotendeels oorspoel is deur die rasionele denke wat tydens die Aufklärung na vore kom en wat tot in so 'n hoë mate vandag ons samelewingsorde bepaal. Hoewel dit waar is dat Calvyn se denke oor wat dit beteken dat die gelowiges God as Heer in alle lewensverbande moet dien en eer, óók bepaal word deur 16e eeuse verhoudings, bly dit vasstaan dat Calvyn steeds in gehoorsaamheid aan die Woord van God alleen hier na antwoorde gesoek het. Daarom bly dit noodsaaklik, as oproep en taak, dat die Calvinisme hier in Suider-Afrika wéér met oop oë na Calvyn se teologie sal kyk om sodoende weer te kom tot gehoorsaamheid aan die Woord alléén. 


\section{Die Kerk}

Die evangelie, so leer Calvyn ons, roep sélf die gemeente, die kerk na vore. Dit beteken dan óók dat die kerk, die verkondiger van die koninkryk van God, 'n besondere rol moet speel. Sonder om hier op allerlei besonderhede in te gaan, is dit duidelik dat by Calvyn die $k e r k$, die moeder van die gelowiges, nie ' $n$ statiese nie maar ' $n$ dinamiese, lewende organisme is wat hy ook met Paulus se vergelyking as die liggaam van Christus aandui. Die kerk wat nié dieselfde is as die koninkryk nie maar wat deur die verbond bepaal word is dié liggaam, díe organisme waardeur God sy orde in hierdie wêreld vestig.

Juis omdat die tema kerk-koninkryk-verbond by Calvyn so ' $n$ boeiende saak is, omdat sy denke in hierdie verband ook so 'n groot bydrae gelewer het tot die vorming van gedagtes, is en bly dit 'n saak wat méér aandag verdien en ook voortgesette navorsing vereis.

Vanuit hierdie tema word dit verder duidelik dat Calvyn' $n$ teoloog is wat nooit die besef verloor dat God die Here en sy bedeling die bepalende is en bly vir mens in sy bedeling en dat die toekoms van die mens nie eensydig in hierdie wêreld lê nie. Saam met 'n duidelik asketiese houding ten opsigte van hierdie wêreld beklemtoon Calvyn dit voortdurend dat hierdie voorlopig deur God self voltooi sal word. Ook hiermee en met hierdie boodskap kan ons verhorisontaliseerde gemeenskap wéér geleer word om nie die laaste hoop en verwagting hier te soek nie.

\section{Slotopmerkings}

Dit is duidelik dat vanuit die sentrale momente van Calvyn se teologie daar meerdere gegewens is wat juis in ons tyd wéér na vore gebring móet word. Dit is miskien nie nodig om hiér te pleit vir vernude aandag vir die werk van Calvyn nie, want dit is duidelik dat sy teologie onder ons nie 'n vreemde saak is nie. Wat miskien wél nodig is, is om wéér te verwys na ' $n$ opmerking van Karl Barth uit 1936 toe hy gesê het:

"Dit was Calvyn wat aan ons teoloë duidelik gemaak het wát die ruimte is waar ons ons werk doen. Hy het dit gedoen deur ons gewoond te maak aan die gedagte dat ons, ten enemale, met al ons inspanning, hoe abstrak en spesiaal dit dikwels ook kan wees, aan niks ánders diensbaar is nie as die kerk en dit beteken dat ons geen ander taak het as om die verkondiging van Gods Woord te dien nie ... Ons is Calvyn dankbaar dat in sy skool 'n kerklik-onverskillige teologie net so onmoontlik is as ' $n$ teologies karakterlose kerk." 
Miskien is dit nodig dat ons met méer aandag as vantevore juis die verkondiging van die regte Woord sal dien sodat dáárdie Woord inderdaad gehoor én gehoorsaam sál word. Teenoor die aanslae wat gemaak word op die gees en denke van ons volk, bestaan daar net één antwoord. Miskien meer as in ander tye besef ons die waarheid van die Pauliniese woord dat die worstelstryd van die kerk en die gelowige nie primêr teen vlees en bloed is nie maar teen "die owerhede, teen die magte, teen die wêreldheersers van die duisternis van hierdie eeu, teen die bose geeste in die lug". In hierdie worstelstryd het die kerkvader Calvyn, vanuit Gods Woord, vir ons 'n reeks uitnemende riglyne neergelê wat ons alleen tot ons eíe skade sal verwaarloos.

Daarom lyk dit my goed as ons hierdie Kongres dan open met die reeds aangehaalde woord van Calvyn:

“Die Here God wil dat sy evangelie verkondig sal word. Ons wil aan hierdie opdrag gehoorsaam wees en gaan waarheen Hy ons roep. Om na resultate te vra is nie ons taak nie."

\section{Aantekeninge}

$1 \mathrm{Vgl}$ in hierdie verband die "sondelys" wat opgestel is deur G W Locher, Reformation als Beharrung und Fortschritt, artikel in Calvinus Theologus, Neukirchen- Vluyn 1976, S 5-6.

$2 \mathrm{Vgl} \mathrm{G}$ Brillenburg-Wurth, Het Calvinisme Vandaag, Wageningen z j, bl 11.

$3 \mathrm{Vgl} \mathrm{B} \mathrm{C} \mathrm{Milner} \mathrm{Jr,} \mathrm{Calvin's} \mathrm{Doctrine} \mathrm{of} \mathrm{the} \mathrm{Church,} \mathrm{Leiden} \mathrm{1910,} \mathrm{p} 46 \mathrm{ff}$.

$4 \mathrm{G}$ Brillenburg-Wurth, Calviin en het Koninkryk Gods, artikel en D Nauta et al, Vier Redevoeringen over Calvijn, Kampen 1959, bl 76. 